\title{
PENURUNAN KADAR Fe DAN Mn PADA AIR SUMUR GALI DENGAN AERASI GELEMBUNG UDARA DI DESA SIDING KECAMATAN BANCAR KABUPATEN TUBAN
}

\author{
Indarti Trisetyani**) dan Joko Sutrisno*)
}

\begin{abstract}
Wells water in the village of Siding, Bancar, Tuban contains Fe and Mn more than maximum limit allowed by the health minister number 416/Menkes/PER/IX/1990, for level of Fe in the clean water should not be more than $1,0 \mathrm{mg} / \mathrm{l}$ and $\mathrm{Mn}$ 0,5 $\mathrm{mg} / \mathrm{l}$. This research aims to reduce the content of $\mathrm{Fe}$ and $\mathrm{Mn}$ in wells water with bubbles aeration so that will meet quality standards of clean water, to find the length of time and effective aeration and decreased $\mathrm{Fe}$ and $\mathrm{Mn}$ from treatment with bubbles aeration. The research is done using a plastic tub of aeration, air supply is done by pumping water size $17 \mathrm{w}$ and nozle size $1,5 \mathrm{~mm}$ by the time variation 20,40 and 60 minutes. Sampling was performed 3 times for each treatment, than analyzed in the laboratory to know the decrease levels of $\mathrm{Fe}$ and $\mathrm{Mn}$. The results of research showed that the levels of Fe and $\mathrm{Mn}$ were high in well water very good to treatment by bubbles aeration. The beginning of level $\mathrm{Fe}$ $3,1 \mathrm{mg} / \mathrm{l}$ and $\mathrm{Mn}$ 0,87 mg/l, after aerated Fe level in water is 0,0037 mg/l and $\mathrm{Mn} 0,0491 \mathrm{mg} / \mathrm{l}$ ( appropriate water quality standards). Average decreased of Fe content after the bubbles aerated from 20 minutes at $90 \%, 40$ minutes at $96 \%, 60$ minutes at $95 \%$ and Mn content after aerated for 20 minutes decreased $51 \%, 40$ minutes $54 \%, 60$ minutes $75 \%$.
\end{abstract}

Key world : Bubbles aeration, Decreased, Fe, Mn, Wells Water,.

\section{PENDAHULUAN}

Air bersih merupakan salah satu kebutuhan pokok mahluk hidup termasuk manusia, tanpa air manusia tidak dapat melangsungkan hidupnya, karena setiap aktifitas manusia memerlukan air misalnya : kegiatan rumah tangga, industri, perkantoran, pertanian dan lainnya. Kebutuhan air dapat dipenuhi dengan cara memanfaatkan sumber air yang tersedia di alam yakni: air hujan, air permukaan dan air tanah. Dari ketiga sumber air tersebut air tanah lebih baik kualitasnya dibandingkan air permukaan dan air hujan, hal ini disebabkan air permukaan dan air hujan lebih mudah tercemar dibandingkan air tanah (Rahmawati, 2005).

Kualitas air tanah dipengaruhi kandungan berbagai mineral dan bahan lainnya sewaktu terjadi proses perembesan sehingga potensi pencemaran tetap dimungkinkan. Mineral dalam air tanah dibuktikan dengan ditemukannya berbagai unsur kimia yang terkandung didalam air tanah. Keberadaan berbagai mineral dalam air tanah ada yang dibutuhkan oleh tubuh, namun ada yang dapat menganggu tubuh. Air memberikan manfaat optimal jika memenuhi syarat kesehatan yang ditetapkan oleh World Health Organization (WHO) yang mempersyaratkan air untuk keperluan air minum harus memenuhi syarat fisik, kimia, mikrobiologi dan radioaktif.

Sesuai dengan ketentuan yang
diatur dalam
No.416/Menkes/PER/IX/1990 PERMENKES
persyaratan kualitas air bersih, yang
mengatur kandungan mineral yang
diperbolehkan
diperbolehkan dalam kadar tertentu diantaranya $\mathrm{Fe}$ dan Mn. Kadar maksimum yang diperbolehkan untuk Besi yaitu 1,0 mg/l dan Mangan 0,5 mg/l.Senyawa besi dalam jumlah kecil didalam tubuh manusia berfungsi sebagai pembentuk sel-sel darah merah, tubuh memerlukan $7-35 \mathrm{mg} / \mathrm{hari}$ yang sebagian diperoleh dari air. Kelebihan zat Besi dalam tubuh dapat menimbulkan masalah kesehatan misalnya merusak dinding usus, iritasi pada kulit dan mata serta gangguan ginjal. Selain itu gangguan teknis seperti mengotori bak, wastafel serta pembuntuan pada perpipaan karena endapan $\mathrm{Fe}(\mathrm{OH})$, juga gangguan fisik misalnya timbulnya warna, bau dan rasa. Air akan terasa tidak enak jika konsentrasi Besi terlarutnya lebih besar dari $1,0 \mathrm{mg} / \mathrm{l}$.

Berdasarkan penelitian terdahulu diantaranya Benny Syahputra (2012) telah melakukan penelitian eksperimen terhadap penurunan kadar besi pada air sumur dengan aerasi dan variasi lama injeksi udara

\footnotetext{
**) Mahasiswa Teknik Lingkungan

*) Dosen Teknik Lingkunag

Universitas PGRI Adi Buana Surabaya
} 
mulai dari 5 menit, 10 menit, 15 menit, 20 menit dan 25 menit. Sedangkan aerator yang digunakan air pump size $5 \mathrm{w}$. Hasil penelitian menunjukkan bahwa penurunan kadar Fe dibawah ambang batas dalam waktu injeksi udara selama 20 menit dengan persentase 44,8

Penduduk desa Siding kebutuhan air bersihnya untuk keperluan sehari-hari sebagian berasal dari air sumur yang kualitasnya kurang memenuhi syarat. Hal ini berdasarkan hasil pemeriksaan laboratorium bahwa secara kimia ada beberapa parameter yang tidak sesuai dengan baku mutu air bersih yaitu kadar Fe sebesar 3,1 $\mathrm{mg} / \mathrm{l}$ dan $\mathrm{Mn}$ 0,87 $\mathrm{mg} / \mathrm{l}$. Oleh karena itu peneliti menjadikan masalah tersebut sebagai bahan dan sumber penelitian. Dan batasan masalah dalam penelitian ini adalah air bersih yaitu air sumur gali yang berasal dari desa Siding kecamatan Bancar kabupaten Tuban.

Berdasarkan identifikasi masalah tersebut maka peneliti merumuskan masalah sebagai berikut : seberapa efektif proses aerasi gelembung udara dalam menurunkan kadar Fe dan Mn pada air sumur gali di desa Siding kecamatan Bancar kabupaten Tuban, apakah variasi waktu aerasi mempengaruhi efektifitas penurunan $\mathrm{Fe}$ dan Mn pada air sumur. Sedangkan tujuan dari penelitian adalah mengetahui kadar $\mathrm{Fe}$ dan $\mathrm{Mn}$ sebelum dan sesudah aerasi, mengetahui efektifitas aerasi gelembung udara dalam menurunkan kadar $\mathrm{Fe}$ dan $\mathrm{Mn}$ pada air sumur dan mengetahui pengaruh variasi waktu aerasi dalam menurunkan $\mathrm{Fe}$ dan $\mathrm{Mn}$. Manfaat dari hasil penelitian ialah sebagai informasi bagi masyarakat dan pengambil keputusan tentang penyediaan air bersih yang berkualitas, bagi masyarakat desa Siding sebagai rencana dan upaya untuk meningkatkan kualitas hidup (air bersih) sehingga tidak terganggu kesehatannya.

Air merupakan salah satu sumber daya alam terbesar yang dianugerahkan Tuhan Yang Maha Esa kepada mahluk hidup di muka bumi ini. Tubuh manusia sebagian besar terdiri dari air kurang lebih $60-80 \%$ dari berat badan manusia. Apabila tubuh kita kehilangan cairan $20 \%$ maka mengakibatkan ketidakseimbangan metabolisme dalam tubuh bahkan dapat mengakibatkan dehidrasi dan kematian. Air yang selama ini berada disekitar kita dan dikonsumsi untuk kebutuhan sehari-hari berasal dari berbagai sumber. Berdasarkan asal sumbernya air dibedakan menjadi 3 , menurut Djafar (2000) yaitu air angkasa (hujan), air permukaan dan air tanah. Beberapa sifat air hujan adalah bersifat lunak karena tidak mengandung mineral dan larutan garam, umumnya bersifat lebih bersih dan dapat bersifat korosif karena mengandung zat-zat yang terdapat diudara seperti $\mathrm{NH}_{3}$ dan $\mathrm{SO}_{2}$. Sedangkan air permukaan misalnya air sungai, danau, rawa, laut dan waduk karakteristik umum dari air ini ialah fluktuasi karena pengaruh musim, lalu untuk kontinuitas dan kuantitasnya dapat dianggap tidak menimbulkan masalah yang besar untuk penyediaan air bersih dengan bahan baku air permukaan.

Air tanah adalah air yang bergerak atau berada dalam tanah yang terdapat dalam ruang antara butiran-butiran tanah dan mengalami pengisian secara terus menerus serta merupakan sumber air yang paling banyak digunakan di daerah pedesaan. Dari segi kesehatan sumber air yang ada di bumi tidaklah selalu memenuhi syarat kesehatan, karena semua mempunyai kemungkinan tercemar misalnya mengandung mineral dan gas-gas tertentu yang menganggu tubuh, karena kandungan zat radioaktif maupun benda-benda koloid seperti bakteri jamur (sesuai dengan keputusan Menteri Negara KL RI No.KEP/02/MENKLH///1998). Selain dipengaruhi oleh musim pencemaran air akan terjadi apabila salah penempatan, konstruksi dan pengoperasian dari sumur tersebut (Margono, 2010). Kandungan mineral atau zat kimia yang selalu ada dalam air tanah adalah $\mathrm{Fe}, \mathrm{Mn}$ dan kesadahan.Besi dan Mangan dalam air berasal dari tanah yang memang mengandung banyak kandungan mineral dan logam yang larut dalam air tanah. Kedua logam ini pada konsentrasi tinggi menyebabkan bercak noda kuning kecoklatan untuk Besi dan kehitaman untuk Mangan, yang sangat menganggu secara estetika. Pada umumnya Besi yang ada dalam air dapat bersifat : terlarut sebagai fero $\left(\mathrm{Fe}^{2+}\right)$ dan tidak terlarut sebagai feri $\left(\mathrm{Fe}^{3+}\right)$, tersuspensi sebagai butiran koloid $\mathrm{Fe}(\mathrm{OH})_{3}$. Adapun Besi terlarut yang berasal dari pipa atau tangki besi adalah akibat dari kondisi antara lain : $\mathrm{PH}$ yang rendah, $\mathrm{O}_{2}$ terlarut dalam air, tingginya suhu air, kuatnya daya hantar listrik dan adanya bakteri besi dalam air.

Besi adalah salah satu elemen kimiawi yang dapat ditemui pada hampir setiap tempat di bumi, pada semua lapisan 
geologis dan semua badan air. Besi merupakan zat tunggal yang secara kimia tidak dapat diuraikan lagi menjadi zat-zat lain yang lebih sederhana dengan karakteristik antara lain : permukaan mengkilap, penghantar listrik dan panas, pada suhu kamar berwujud padat, masuk golongan VIII dari tabel periodik, lambang atom $\mathrm{Fe}$, nomor atom 26 (Supriyadi, 2010). Di dalam tanah berada dalam batuan yang tidak mudah larut dan berbentuk ferrioksida serta ferrous carbonat yang sedikit larut dalam air. Apabila konsentrasi Besi terlarut dalam air melebihi batas yang dipersyaratkan maka akan menyebabkan masalah yaitu gangguan teknis, fisik dan kesehatan.

Aerasi adalah proses pengolahan air dengan cara mengontakkannya dengan udara. Aerasi secara luas telah digunakan untuk pengolahan air yang mempunyai kandungan jumlah $\mathrm{Fe}$ yang terlalu tinggi. Untuk pengolahan air bersih kebanyakan dilakukan dengan menyebarkan air agar kontak dengan udara atau mencampur air dengan gelembung-gelembung udara (Said $\mathrm{N}, \mathrm{I}) 2005$. Proses penurunan kadar $\mathrm{Fe}$ melalui aerasi yaitu oksigen yang ada diudara akan bereaksi dengan senyawa ferus terlarut menjadi feric yang tidak bisa larut. Tujuan dari proses aerasi adalah untuk penambahan jumlah $\mathrm{O}_{2}$, penurunan jumlah $\mathrm{CO}_{2}$, menghilangkan $\mathrm{H}_{2} \mathrm{~S}$ dan $\mathrm{CH}_{4}$ serta berbagai senyawa organik yang bersifat volatil (menguap) yang berkaitan dengan rasa dan bau. Dalam proses pengolahan air, aerasi dipergunakan pula untuk menghilangkan gas-gas terlarut. Oksidasi kandungan Besi dalam air mereduksi kandungan ammonia dalam air melalui proses nitrifikasi dan untuk meningkatkan oksigen terlarut agar air terasa lebih segar. Menurut Ditjen PPM dan PLP Direktorat Penyehatan Depkes RI (1990) aerator dibedakan menjadi 5 yang salah satunya ialah aerasi gelembung udara (bubble aerasi). Jenis aerasi ini udara disemprotkan melalui dasar bak air yang akan diaerasi, sehingga udara akan kontak dengan air atau mencampur air dengan gelembung udara. Dari aerasi gelembung udara ini oksigen pada air bisa dinaikkan hingga $60-80 \%$ (dari jumlah oksigen yang tertinggal yaitu air yang mengandung oksigen sampai jenuh). Sedangkan oksidator utama adalah molekul oksigen dari udara, klorin atau $\mathrm{KMnO}_{4}$ dan untuk kecepatan pengendapan dipengaruhi oleh jenis dan kadar oksidator, $\mathrm{PH}$, kesadahan dan kemungkinan ditambahkannya katalisator.

\section{METODE PENELITIAN}

Metode penelitian merupakan cara yang ditempuh melalui proses ilmiah dalam mencari kebenaran. Cara ilmiah dalam mencapai hasil yang benar adalah melalui penelitian yang dikenal sebagai pengetahuan terhadap epistemology. Yaitu pengetahuan tentang bagaimana cara untuk mengetahui dan mempelajari sesuatu dalam memperoleh kebenaran (Notoatmodjo S, 1993).

Desain penelitian sesuai dengan judul "Penurunan kadar Fe dan Mn pada air sumur gali dengan aerasi gelembung udara di desa Siding kecamatan Bancar kabupaten Tuban" adalah eksperimen yaitu penelitian yang bertujuan mengetahui efektifitas aerasi gelembung udara dengan variasi waktu aerasi terhadap kualitas air bersih di desa Siding, kecamatan Bancar, kabupaten Tuban terutama nilai kadar Fe dan Mn. Dengan cara membuat alat treatment, eksperimen, mengumpulkan data, menganalisa data dan menarik 
Indarti Trisetyani \& Joko Sutrisno : Penurunan Kadar Fe Dan Mn Pada Air Sumur Gali Dengan Aerasi Gelembung Udara Di Desa Siding Kecamatan Bancar Kabupaten Tuban

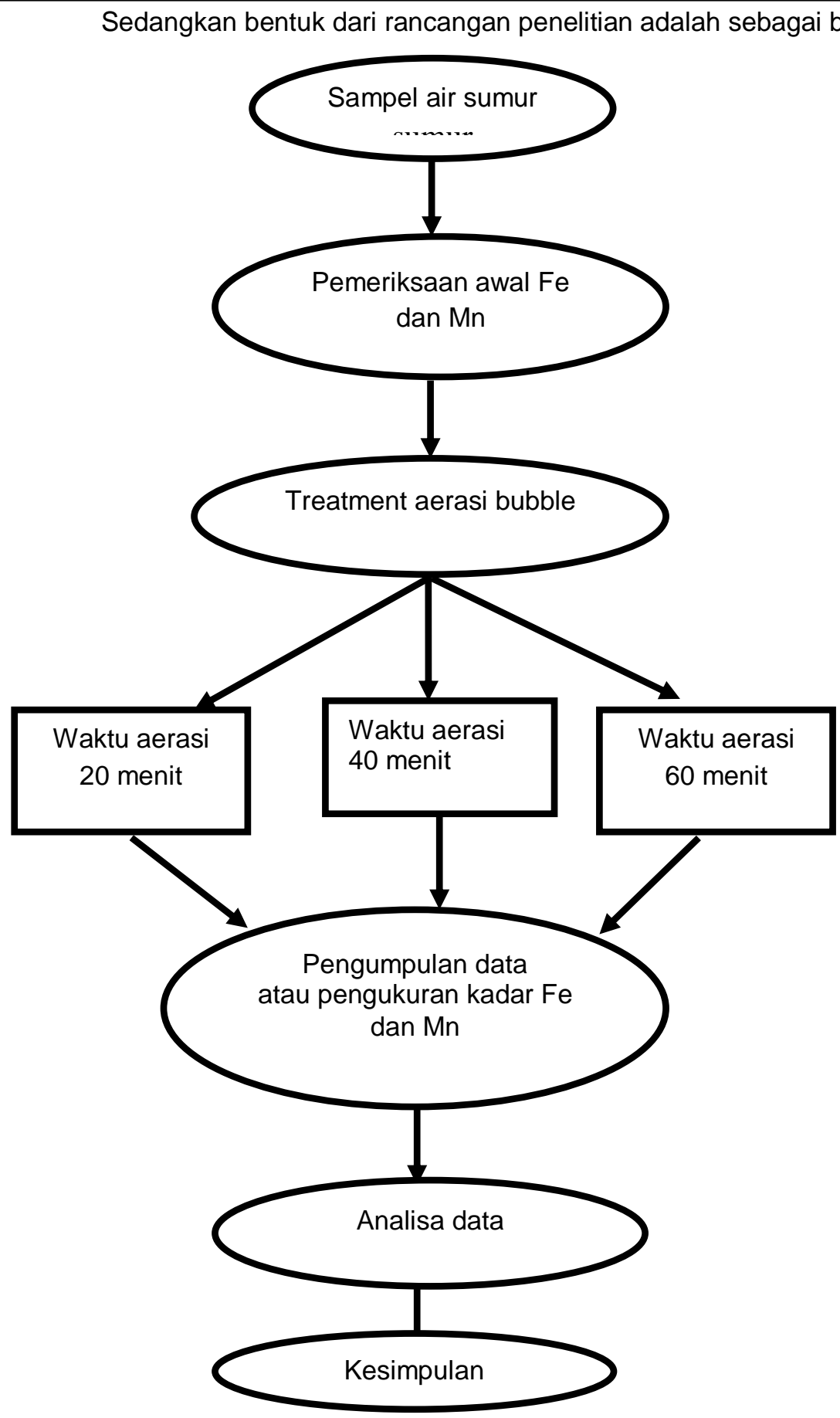

Gambar 1. Skema Rancangan Penelitian

Dalam penelitian ini yang menjadi variabel terikat yaitu kandungan $\mathrm{Fe}$ dan $\mathrm{Mn}$ pada air sumur gali di desa Siding sedangkan variabel bebasnya adalah variasi waktu aerasi pada proses aerasi gelembung udara serta variabel kontrolnya ialah sumber air bersih berasal dari sumur gali desa Siding kecamatan Bancar kabupaten Tuban, dengan kadar $\mathrm{Fe}$ awal 3,1 mg/l dan $\mathrm{Mn} \mathrm{0,87}$ $\mathrm{mg} / \mathrm{l}$. Sedangkan definisi operasional aerasi gelembung udara adalah proses pengolahan air dengan mencampur air dan gelembunggelembung udara. Kadar Besi ialah konsentrasi $\mathrm{Fe}$ dalam satuan $\mathrm{mg} / \mathrm{l}$ pada air sumur gali sebelum dan sesudah treatment diukur dengan spektrofotometer. Kadar Mangan adalah konsentrasi $\mathrm{Mn}$ dalam satuan $\mathrm{mg} / \mathrm{l}$ pada air sumur sebelum dan sesudah treatment yang diukur secara kolometri dengan metode persulfat. 
Deskripsi populasi adalah populasi (obyek) dalam penelitian yang penulis teliti. Dalam penelitian ini yang menjadi obyek adalah air sumur gali desa Siding kecamatan Bancar kabupaten Tuban. Sedangkan sampel pada penelitian ini adalah air sumur gali yangberada di desa Siding RT:2 RW : 5 dengan pemilik bapak Kosim, yang diambil sebelum dan sesudah treatment selanjutnya dilakukan pemeriksaan ke laboratorium.

Waktu yang digunakan untuk penelitian adalah bulan oktober sampai dengan desember 2013. Tempat penelitian di RT : 2 RW : 5, desa Siding kecamatan Bancar kabupaten Tuban. Tempat analisa hasil eksperimen di Balai Besar Teknik Lingkungan Surabaya dan Laboratorium Kesehatan kabupaten Tuban.

Data yang dikumpulkan meliputi data primer dan sekunder dengan metode penelitian secara eksperimen. Data primer diperoleh dari hasil eksperimen penurunan kadar $\mathrm{Fe}$ dan $\mathrm{Mn}$ dengan aerasi gelembung udara, sedangkan data sekunder diperoleh dari dokumentasi (Monografi Desa Siding) dan pengamatan di lapangan. Dari $662 \mathrm{KK}$ di desa Siding semua memakai air sumur untuk kegiatan rumah tangga, peternakan dan pertanian. Sedangkan yang kualitas airnya secara fisik tidak baik ada $59 \mathrm{KK}$, salah satunya air yang digunakan keluarga bapak Kosim.

Prosedur eksperimen dalam penelitian ini meliputi tahapan sebagai berikut : penyajian alat dan bahan (pompa air, tandon, kayu penyangga bak aerasi, pipa PVC, bak aerasi, aerator, kran air, selang, stop watch dan timba). Prosedur penelitian : membuat penyangga bak aerasi dari kayu, kemudian melubangi bak aerasi dan memasang paralon serta kran, merakit aerator dengan memasang 6 selang $1 \mathrm{~m}$ pada mulut nozzel, memastikan peralatan bersih dari parameter yang akan diuji dan aerator berfungsi baik, memasang alat dan bahan sesuai dengan rencana konstruksi yang ditetapkan, selanjutnya air sampel dinaikkan ke tandon dengan bantuan pompa, kemudian air turun melalui pipa ke bak aerasi (proses aerasi terjadi dari atas kebawah dengan air pump $17 \mathrm{w}$, waktu aerasi mulai dari 20, 40 dan 60 menit), setelah dari bak aerasi air sampel ditampung di bak hasil treatment (jerigen 2 liter) dan selanjutnya diujikan ke laboratorium.

Pemeriksaan $\mathrm{Fe}$ dan $\mathrm{Mn}$ dilakukan secara langsung baik sebelum dan sesudah eksperimen sehingga hasilnya langsung bisa diketahui. Metode analisa sampel mengacu pada SNI 06.6989.4.2009 untuk kadar $\mathrm{Fe}$ dan SNI 06.6989.5.2009 untuk kadar Mn. 1. Penentuan Fe (Besi) : air sampel yang akan diperiksa dikocok dulu lalu disaring dan diambil $25 \mathrm{ml}$ dan dimasukkan ke labu erlenmeyer, menambahkan $1 \mathrm{ml} \mathrm{HCl}$ untuk melarutkan $\mathrm{Fe}(\mathrm{OH})_{3}$, menambahkan $0,5 \mathrm{ml}$ $\mathrm{NH}_{2} \mathrm{OH}$, memanaskan hingga volume menjadi 15-20 $\mathrm{ml}$, mendinginkan dan mengencerkan dengan aquades hingga volume menjadi $25 \mathrm{ml}$, menambahkan $5 \mathrm{ml}$ larutan amonium acetate buffer, menambahkan $1 \mathrm{ml}$ phenanthroline, melakukan pengukuran warna secara visual dengan specthrofotometer. . 2.Penentuan Mn (Mangan): menggocok lalu menyaring air sampel kemudian mengambil $25 \mathrm{ml}$ sampel dan dimasukkan dalam erlenmeyer $100 \mathrm{ml}$ lalu menambahkan 3 tetes asam nitrat pekat, menitrasi dengan laruta $\mathrm{AgNO}_{3}$ sampai timbul endapan, memanaskan sampel sebelum mendidih tambahkan 1 spatula kristal $\mathrm{K}_{2} \mathrm{~S}_{2} \mathrm{O}_{4}$, setelah mendidih mengamati perubahan warnanya (bila warna xiolet berarti $\mathrm{Mn}$ positif ada), mengambil 6 buah tabund nessler lalu diisi aquades masing-masing $50 \mathrm{ml}$, menambahkan $0,1 \mathrm{ml} \mathrm{KMnO}_{4}$ pada tabung pertama, 0,2 $\mathrm{ml} \mathrm{KMnO}_{4}$ pada tabung kedua dan begitu seterusnya sampai tabung ke-6, menghitung kadar Mn dengan mencocokkan warna sampel yang diperiksa dengan warna yang ada pada tabung nessler.

Sedangkan metode analisa data yang digunakan pada penelitian ini adalah metode deskriptif penurunan $\mathrm{Fe}$ dan $\mathrm{Mn}$ pada setiap variabel dengan menggunakan grafik dan tabel.

\section{HASIL PENELITIAN}

Desa Siding merupakan salah satu wilayah yang berada di kecamatan Bancar kabupaten Tuban. Mayoritas penduduknya menggunakan air sumur untuk keperluan sehari-hari sebagai sumber air bersih. Masyarakat mulai dari mencuci, mandi, memasak, menyiram dan keperluan pertanian memanfaatkan air sumur yang diperoleh dari dalam tanah.

Sedangkan sebagian besar sekitar lokasi sumur yang diteliti memang kondisi fisik airnya tidak baik. Uji organoleptis yang diperoleh antara lain : air berwarna kuning kemerahan, air berbau karat, bila air mengenai kulit berasa ketat, ada endapan berwarna kuning dan terdapat lapisan minyak pada bagian atas air.Keadaan tersebut masih banyak dijumpai pada air tanah yang ada di desa Siding dan 
dimanfaatkan oleh masyarakat sebagai sumber air bersih, yang sebenarnya kurang baik untuk digunakan karena dapat menganggu estetika (menodai pakaian dan perkakas rumah tangga, menghitamkan pemasakan beras, memberikan rasa pahit pada air) serta menganggu kesehatan dan pembuntuan pada perpipaan.

Setelah peneliti

melalukan pengambilan dan pemeriksaan sampel air sumur gali, maka peneliti telah mendapatkan data-data yang meliputi data kadar Fe dan Mn sebelum dan sesudah diberi treatment yaitu dengan melewatkan sampel pada bak aerasi, yang menggunakan 3 variasi waktu aerasi selama 20, 40 dan 60 menit.
Pengambilan sampel dilakukan 3 hari sedangkan aerator yang digunakan adalah air pump dengan kapasitas 17 watt. Setelah diaerasi sampel ditampung dalam wadah (jerigen 2 liter) kemudian ditetesi reagen $\mathrm{H}_{2} \mathrm{SO}_{4}$ sebanyak 2 tetes agar tidak terjadi perubahan komposisi selama perjalanan.

Sedangkan data hasil pemeriksaan laboratorium parameter $\mathrm{Fe}$ dan Mn pada air sumur gali di desa Siding kecamatan Bancar kabupaten Tuban sebelum dan sesudah dilakukan aerasi gelembung udara seperti tersebut dibawah ini, yang selanjutnya dilakukan perhitungan rata-rata penurunannya. Adapun rata-rata penurunan Fe dan Mn seperti pada tabel1 dan 2 berikut.

Tabel 1. Rata-Rata Penurunan Kadar Fe

\begin{tabular}{cccccc}
\hline No & Fe awal $(\mathrm{mg} / \mathrm{l})$ & Waktu aerasi & Fe akhir $(\mathrm{mg} / \mathrm{l})$ & Penurunan & Efisiensi $(\%)$ \\
\hline 1 & 3,1 & 20 & 0,1573 & 2,9477 & 94,9 \\
2 & 3,1 & 20 & 0,2612 & 2,8388 & 91,5 \\
3 & 3,1 & 20 & 0,0037 & 3,0963 & 99,8 \\
& Rata-rata & & & & 95,4 \\
1 & 3,1 & 40 & 0,1963 & 2,9037 & 93,6 \\
2 & 3,1 & 40 & 0,1540 & 2,946 & 95 \\
3 & 3,1 & 40 & 0,0037 & 3,0963 & 99,8 \\
& Rata-rata & & & & 96,1 \\
1 & 3,1 & 60 & 0,2267 & 2,8733 & 92,6 \\
2 & 3,1 & 60 & 0,2569 & 2,8401 & 91,6 \\
3 & 3,1 & 60 & 0,0037 & 3,0963 & 99,8 \\
& Rata-rata & & & & 94,6 \\
\hline
\end{tabular}

Tabel 2. Rata-Rata Penurunan Kadar Mn

\begin{tabular}{cccccc}
\hline No & Mn awal (mg/l) & Waktu aerasi & $\begin{array}{c}\text { Mn akhir } \\
(\mathrm{mg} / \mathrm{l})\end{array}$ & Penurunan & Efisiensi (\%) \\
\hline 1 & 0,87 & 20 & 0,0491 & 0,8209 & 94,3 \\
2 & 0,87 & 20 & 0,3880 & 0,482 & 55,4 \\
3 & 0,87 & 20 & 0,8337 & 0,0363 & 4,1 \\
& Rata-rata & & & & 51,3 \\
1 & 0,87 & 40 & 0,3133 & 0,5567 & 63,9 \\
2 & 0,87 & 40 & 0,3007 & 0,5693 & 65,4 \\
3 & 0,87 & 40 & 0,5781 & 0,2919 & 33,5 \\
& Rata-rata & & & & 54,2 \\
1 & 0,87 & 60 & 0,0491 & 0,8209 & 81,3 \\
2 & 0,87 & 60 & 0,1005 & 0,7695 & 88,4 \\
3 & 0,87 & 60 & 0,3890 & 0,481 & 55,2 \\
& Rata-rata & & & & 74,9 \\
\hline
\end{tabular}

Berdasarkan tabel 1 dan 2 adalah rata-rata hasil penurunan kadar Fe dan Mn pada air sumur gali dengan aerasi gelembung udara di desa Siding kecamatan Bancar kabupaten Tuban,yang selanjutnya akan dipaparkan dalam bentuk grafik (gambar 2 dan 3 ) berikut: 


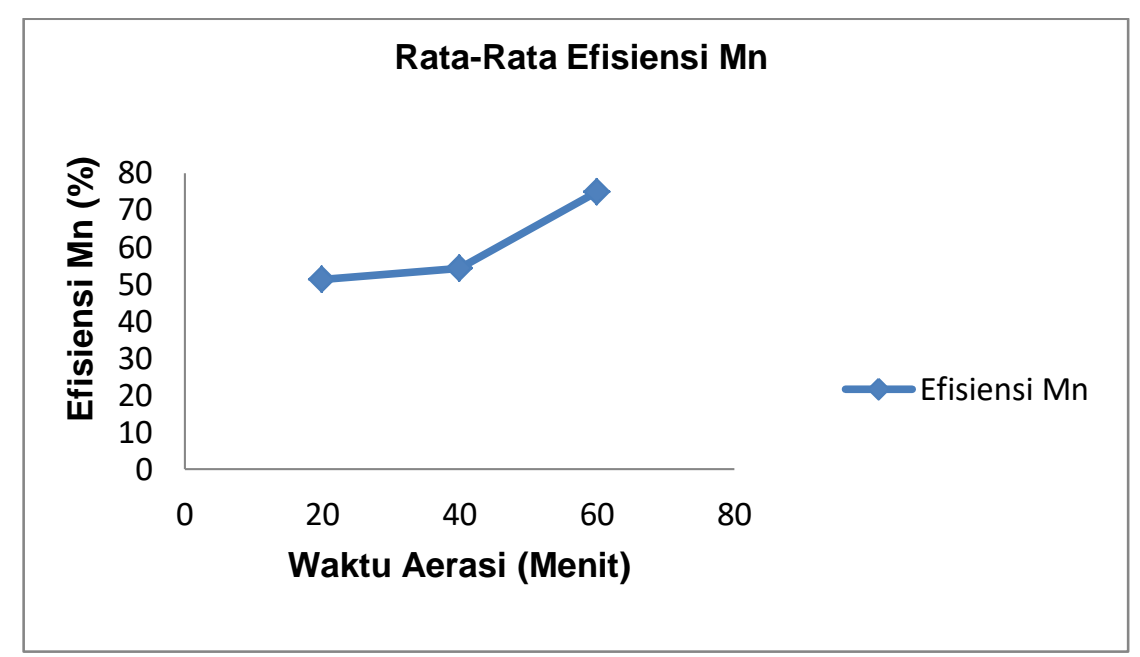

Gambar 2. Grafik Rata-Rata Efisiensi Mangan

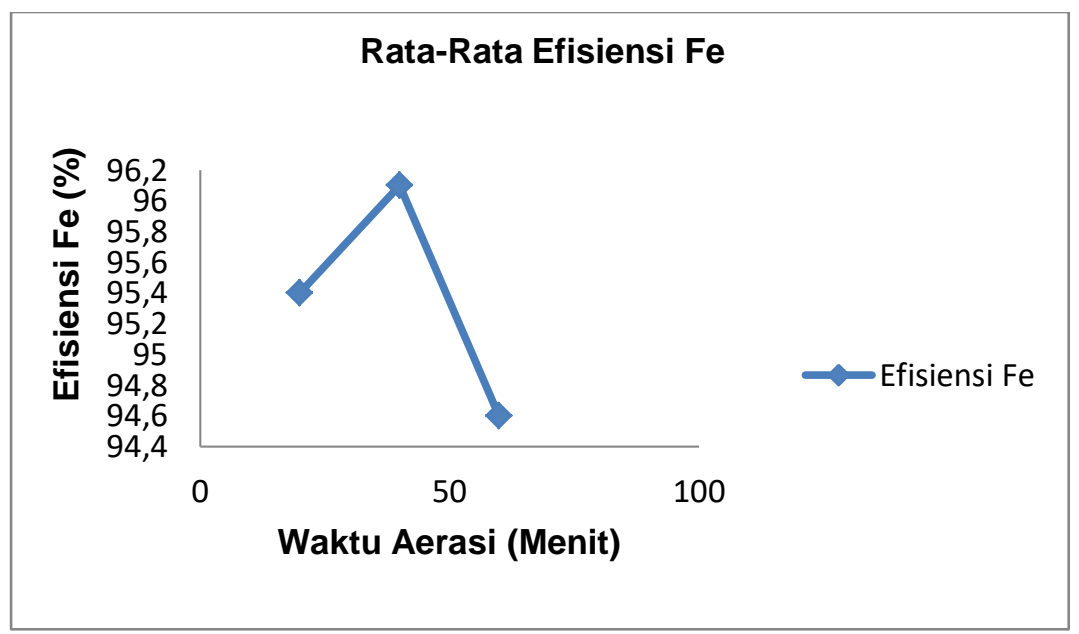

Gambar 3. Grafik Rata-Rata Efisiensi Besi

\section{PEMBAHASAN}

Oksidasi Fe dan Mn dengan aerasi gelembung udara memberikan prospek baik karena dapat digunakan sebagai awal (pre treatment) terhadap air tanah yang mengandung kadar Besi dan Mangan cukup tinggi yang sulit teroksidasi dengan pengolahan biasa. Oksidasi dengan udara atau aerasi akan terjadi reaksi ion sebagai berikut : $4 \mathrm{Fe}^{2+}+\mathrm{O}_{2}+10 \mathrm{H}_{2} \mathrm{O} \rightarrow 4 \mathrm{Fe}(\mathrm{OH})_{3}$ $+8 \mathrm{H}^{+}$. Aerasi air sumur dengan variasi waktu aerasi 20, 40 dan 60 menit tidak berpengaruh signifikan terhadap penurunan kadar Fe dan $\mathrm{Mn}$, karena dalam penelitian tidak dilakukan proses pengendapan setelah aerasi. Penurunan kadar Fe dan Mn pada air sumur dengan aerasi gelembung udara di desa Siding, kecamatan Bancar, kabupaten Tuban memenuhi baku mutu air bersih(PERMENKES

No.416/Menkes/PER/IX/1990) dan sesuai dengan penelitian terdahulu.

\section{KESIMPULAN DAN SARAN Kesimpulan}

Pada penelitian yang telah dilakukan, maka peneliti dapat menyimpulkan sebagai berikut : Kadar $\mathrm{Fe}$ dan Mn sebelum diaerasi pada air sumur di desa Siding kecamatan Bancar kabupaten Tuban sebesar $3,1 \mathrm{mg} / \mathrm{l}$ dan $0,87 \mathrm{mg} / \mathrm{l}$, sehingga belum memenuhi baku mutu air bersih sesuai PERMENKES No.416/Menkes/PER/IX/1990.Aerasi gelembung udara dapat menurunkan $\mathrm{Fe}$ sebesar $96 \%$ dicapai pada aerasi selama 40 menit.Aerasi gelembung udara dapat menurunkan Mn sebesar $75 \%$ dicapai pada aerasi selama 60 menit.Tidak ada pengaruh lama aerasi gelembung udara mulai dari 20 , 40 dan 60 menit.

\section{Saran}

Saran yang perlu disampaikan peneliti pada semua pihak adalah :Perlu 
Indarti Trisetyani \& Joko Sutrisno : Penurunan Kadar Fe Dan Mn Pada Air Sumur Gali Dengan Aerasi Gelembung Udara Di Desa Siding Kecamatan Bancar Kabupaten Tuban

penelitian lebih lanjut tentang penurunan kadar Fe dan Mn pada air sumur dengan proses yang sama tetapi sampel diendapkan
dahulu.Tehnologi ini cocok menurunkan kadar Fe dan Mn jadi perlu diterapkan di masyarakat.

\section{DAFTAR PUSTAKA}

Benny Syahputra, Hermin Poedjiastoeti, 2012. Penurunan Fe pada Air Sumur dengan Aerasi, http://www.journal.unissula.ac.id>home>vol14,no. (diunduh pada tanggal 15 juni 2013)

, 1998.BukuPedoman Penyehatan Air, Depkes RI, Jakarta.

1990. Peraturan Menkes RI No.416/Menkes/PER/IX/1990 tentang Syarat-Syarat dan Pengawasan Kualitas Air, Depkes RI, Jakarta.

--------,1998. KeputusanMenteri Negara KL RI No 02/MENKLH/I/1998 tentang Pedoman Penetapan Baku Mutu Lingkungan. Dep.KLH, Jakarta.

Djafar, 2000. Penyediaan Air Bersih, Fakultas Kesehatan Masyarakat, Unhas, Makasar

Erlani, 2011. Variasi Luas Wilayah Cascade Terhadap Penurunan Kadar Fe (Besi) Air, http://www.sanitasi-keslingmks-biogspot.com. $\quad$ (diunduh pada tanggal 10 juni 2013)

Hermana, J, Voijant B, dan Samodra M.A (2001). Laboratorium Lingkungan. Jurusan Teknik Lingkungan FTSP ITS, Surabaya.

Margono, 2010. Buku Kridha Nirmala, Poltekkes Kemenkes Surabaya.

Muntu, 2003.Air dan Kesehatan. Jurusan Kesehatan Lingkungan Poltekkes, Makasar.

Notoatmodjo,S, 1993. Metodologi Penelitian Kesehatan, Rineka Cipta, Jakarta.

Rahmawati, 2005. Efektifitas Penurunan Kadar Mangan (Mn) dengan Metode KombinasiAerasi dan Penyaringan Pada Air Sumur Gali. Poltekkes, Makasar.

Supriyadi, 2010. Buku Kimia Kelas IX. Lembaga Pendidikan Primagama, Yogyakarta

Said, N, I, 2005. Metode praktis menurunkan besi (Fe) dan mangan (Mn) dalam air minum, Hakli. http://www.enviro.bppt.go.id/-kel-1/ (diunduh pada tanggal 5 januari 2014) 